ScIDice

\section{Comparative Evaluation on the Levels of Salivary Mucin MUC1 in Precancerous and Cancerous Conditions}

Research Article

Rukhsaar Akbar Gulzar1*, Ajitha P², Haripriya Subbaiyan³

${ }^{1}$ Post Graduate Student, Department of Conservative Dentistry and Endodontics, Saveetha Institute of Medical and Technical Science, Saveetha University, Chennai 600077, India.

${ }^{2}$ Professor, Department of Conservative Dentistry and Endodontics, Saveetha Dental College and Hospitals, Saveetha Institute of Medical and Technical Science, Saveetha University, Chennai 600077, India.

${ }^{3}$ Senior Lecturer, Department of Conservative Dentistry and Endodontics, Saveetha Dental College and Hospitals, Saveetha Institute of Medical and Technical Sciences, Saveetha University, Chennai, India.

Abstract

Introduction and Aim: Mucin MUC1, a protein present in saliva plays a role in protecting the epithelium. Mucins are glycoproteins that play a role in cell signalling thus serving a potential biomarker for malignant changes in the epithelium. The aim of the present study was to assess and compare the level of salivary MUC1 in individuals diagnosed with Squamous Cell Carcinoma, oral Premalignancies and compare it to the level of salivary MUC1 in disease free individuals.

Materials and Method: The study samples were divided in three groups with a sample size of 10 in each group. Group A consisted of individuals diagnosed with oral Squamous Cell Carcinoma, group B consisted of individuals diagnosed with oral Premalignancies and group $\mathrm{C}$ was the control group. The levels of salivary mucin MUC1 was estimated using ELISA test. For statistical analysis, data was subjected to ANOVA test and significance was set at $\mathrm{p}<0.05$.

Results: The levels of salivary mucin MUC1 was highest in patients diagnosed with squamous cell carcinoma $(19.33 \pm 4.39$ $\mathrm{ng} / \mathrm{ml})$ followed by premalignant diseases $(8.32 \pm 3.08 \mathrm{ng} / \mathrm{ml})$ and it was the lowest in the control group $(2.73 \pm 0.34 \mathrm{ng} / \mathrm{ml})$ and the results were statistically significant.

Conclusion: An alteration in MUC1 protein could play a role in the pathogenesis and progression of epithelial diseases and thus could serve as a biomarker for its malignant changes.

Keywords: Biomarker; MUC1; Oral Premalignancy; Oral Squamous Cell Carcinoma; Saliva.

\section{Introduction}

Oral cancer ranks from the sixth to the eight most common forms of prevalent cancer and $90 \%$ of oral cancers in South Asia arise from an existing premalignant disease (PMD) such as leukoplakia, erythroplakia and oral submucous fibrosis. Early detection of cancerous diseases poses a challenge due to the lack of awareness of the symptoms and risk factors among the public and lack of adequate prognostic markers. [1-4] The gold standard for oral cancer diagnosis has been tissue biopsy with histological assessment, but these techniques are invasive, painful, time consuming and requires specific training.

Saliva has been extensively studied as a potential non-invasive di- agnostic tool for the early detection of various systemic and oral diseases. Specific salivary biomarkers have been identified for the detection of breast cancer, oral cancer, caries, periodontal diseases and various systemic diseases. Amongst these biomarkers are salivary proteins which are indicators for the physiological and pathological state. [5-7]

Salivary Mucins are a group of such proteins, which are large glycoproteins. They are a structural component of mucous which forms a protective coat over the enamel and oral mucosa. There are at least 20 mucins which have been identified in the human body and the localization and function of each mucin is dictated by the unique structure they possess. Salivary mucins are classified based on their molecular weight into high molecular weight

*Corresponding Author:

Rukhsaar Akbar Gulzar,

Post Graduate Student, Department of Conservative Dentistry and Endodontics, Saveetha Institute of Medical and Technical Science, Saveetha University, Chennai 600077, India. Tel: 9082628669

E-mail: rukhsaar.gulzar@gmail.com

Received: May 20, 2021

Accepted: August 5, 2021

Published: August 14, 2021

Citation: Rukhsaar Akbar Gulzar, Ajitha P, Haripriya Subbaiyan. Comparative Evaluation on the Levels of Salivary Mucin MUC1 in Precancerous and Cancerous Conditions. Int J Dentistry Oral Sci. 2021;8(8):3734-3737. doi: http://dx.doi.org/10.19070/2377-8075-21000765

Copyright: Rukhsaar Akbar Gulzar ${ }^{\circ}$ 2021. This is an open-access article distributed under the terms of the Creative Commons Attribution License, which permits unrestricted use, distribution and reproduction in any medium, provided the original author and source are credited. 
mucins which weigh more than $1000 \mathrm{kDa}$ and lower molecular weight mucins which weigh 200 to $300 \mathrm{kDa}$. Further, epithelial mucins (MUCs) can be classified into two main families as secreted and membrane bound MUCs. They play a pivotal role in the maintenance of oral health and mucosal defence by playing a role in regulating cell growth, differentiation and cell signalling. [8-10] When the levels of mucins are unregulated, they affect the health of the host. MUC1 has been detected in epithelial tissues whose expression is upregulated during cancerous conditions. [11]

Previously our team has a rich experience in working on various research projects across multiple disciplines Now the growing trend in this area motivated us to pursue this project [12-26]. Thus, the present study was conducted to investigate the correlation between the salivary levels of MUC1 and epithelial changes occurring during pre-malignancies and malignancies imparting its role as a non-invasive diagnostic marker.

\section{Materials And Method}

\section{Study Population}

The present study consisted of three groups. Group A consisted of individuals newly diagnosed with oral squamous cell carcinoma, group B consisted of individuals newly diagnosed with oral premalignant diseases and group $\mathrm{C}$ was the control group which consisted of individuals with healthy mucosa and no systemic or oral disease. Individuals who were already undergoing treatment were excluded from the study. A sample size of 10 per group was determined for the present pilot study and hence the total sample size was 30 .

The study was approved by the ethical committee and the patients were asked to sign an informed consent.

\section{Salivary Sample Collection}

All salivary samples were collected between 9am and 12 noon. Unstimulated saliva was collected for a duration of $10 \mathrm{mins}$ by asking the patient to pool the saliva and then spit it in a sterilized container. Before collection of the saliva, all patients were abstained from eating and drinking for $2 \mathrm{hrs}$.

\section{Analysis of Salivary MUC1}

Micro ELISA plate was pre-coated with an antibody that is specific to MUC1. The saliva samples (100ul) were then added to the micro ELISA plate wells and combined with the specific an- tibody. Then a successive addition of biotinylated detection antibody which is specific for Human MUC1 and Avidin-Horseradish Peroxidase (HRP) conjugate was done in each microplate well and incubated. Only those wells that contained Human MUC1, biotinylated detection antibody and Avidin-HRP conjugate appeared blue in colour. The enzyme-substrate reaction was terminated by the addition of stop solution and the colour turned yellow. The measurement of the optical density (OD) was done at a wavelength of $450 \mathrm{~nm}$ spectrophotometrically. The OD value was proportional to the concentration of Human MUC1.

\section{Statistical Analysis}

For statistical analysis, data was subjected to ANOVA test. A level of significance was set at $\mathrm{p} 0.05$. The statistical analysis was done using the SPSS statistical package (version 22.0)

\section{Results And Discussion}

The study revealed that the levels of MUC1 in saliva were higher in patients diagnosed with squamous cell carcinoma $(19.33 \pm 4.39$ $\mathrm{ng} / \mathrm{ml})$ and premalignant diseases $(8.32 \pm 3.08 \mathrm{ng} / \mathrm{ml})$ as compared with the control group $(2.73 \pm 0.34 \mathrm{ng} / \mathrm{ml})$. When the levels of MUC1 in saliva were compared between patients with oral squamous cell carcinoma and pre malignant diseases, the levels were found to be higher in the salivary samples of patients diagnosed with oral squamous cell carcinoma and the values were statistically significant $(\mathrm{p}<0.05)$.

Our institution is passionate about high quality evidence based research and has excelled in various fields [16, 27-36].

Oral squamous cell carcinoma is one of the most common forms of oral malignancies in the oral cavity. In India, it accounts for $8 \%$ of all cancers in females and $12 \%$ of all cancers in Male. [37] A premalignant disease possesses the risk of developing into a malignancy in future. In 2005 WHO defined premalignant disease as "the risk of malignancy being present in a lesion or condition either at time of initial diagnosis or a future date." Leukoplakia has been defined as "a white plaque of questionable risk having excluded other known diseases or disorders that carry no increased risk of cancer." Previous studies have shown a malignant transformation rate of Leukoplakia to be up to 3.6 to $17.5 \%$. Oral Submucous Fibrosis is a chronic debilitating disease of the oral cavity associated with the chewing of arecanut and has been shown to have a malignant transformation rate of 0.6 to $7 \%$. [38, 39] The prognostic factors associated with Oral Squamous Cell Carcinoma are associated with the genetic profile of the epithelial

Figure 1: Graph representing the level of MUC1 in saliva in carcinoma, premalignant disease and control group. $\mathrm{X}$ axis represents the three groups and $\mathrm{Y}$ axis represents the level of MUC1 expressed in $\mathrm{ng} / \mathrm{ml}$, showing that MUC1 levels were significantly higher in patients with squamous cell carcinoma.

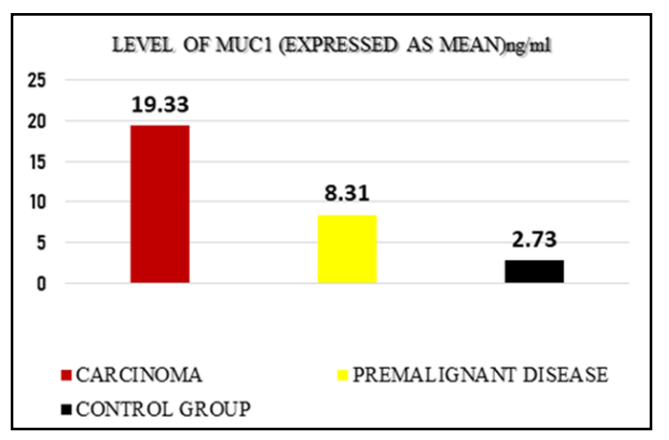


cells showing malignancy which in turn reflects their tumor aggressiveness. [40]

Mucous forms a wet coating over the epithelial surfaces throughout the body. Mucins are the gel forming component of Mucous, which are proteins that are heavily glycosylated and act as molecular barriers. They are involved in the morphogenetic signal transduction pathways. Their biochemical and biophysical properties of visco-elastic secretions are governed by their glycosylation content. [41] Thus, each of the salivary mucins contain unique domain structures that influence their properties and localization in the oral cavity. Mucins comprise of $15-20 \%$ protein and $80 \%$ carbohydrate which are present in the form of O-linked glycans. The most abundant amino acids are Serine and Threonine which serve as the site for attachment of these carbohydrates. The monomeric molecular weight of most mucins is greater than 2 million daltons and their multimers weigh ten times the weight of their monomers. Their high degree of glycosylation and their large size give them the very property which allows them to function as protective molecules. Based on the information available on their structure, mucins have been classified into three broad categories namely, Large gel forming mucins (MUC2, MUC5AC, MUC5B and MUC6), large membrane associated mucins (MUC1, MUC3, MUC4 and MUC12) and the small soluble mucins (MUC7). Amongst the 20 identified mucins in the human body, MUC5B, MUC7, MUC19, MUC1, and MUC4 are found in the saliva. The mucous cells of the submandibular, sublingual, palatine and labial salivary glands secrete MUC5B that is the major gel forming mucin in the oral cavity. MUC7 is another secreted mucin but it lacks the property of forming gel. MUC4 and MUC1 are associated with membranes and are found lining the ducts of the salivary glands. These play a key role in biological activities of cell signalling, cell adhesions, differentiation and cellular immune response. The development of a malignant disease and its progression has been associated with the alteration in the expression of their glycosylation. [42] The membrane bound MUC1 and MUC4 could serve for protection of the epithelial surface in two ways, firstly the heavily glycosylated rod like mucin molecules would form a multi layered physical barrier on the surface of the cells, preventing access of bacteria, fungi, viruses and other harmful agents. Secondly, MUC1 and MUC4 could form a scaffold or a structural framework upon which MUC5B which is a gel forming mucin assembles. This resulting complex would strengthen the protective barrier and increase the lifetime of secreted mucins in the oral cavity. Thus, mucins can be used markers to detect a diseased condition involving the epithelium. [42]

A vast literature has accumulated the role of MUC1 in tumor progression and metastasis. [43] MUC1 has been shown to exist in both membrane associated form and the secreted form. The soluble form of MUC1 is probably due to the shedding of the extracellular subunits. The $\mathrm{N}$-terminal extracellular region has 3 domains: tandem repeat domains comprising 420 to 2500 residues, a unique 107 residue domain and a second unique 277- residue domain. The extracellular region is followed by a membrane spanning domain of 27 residue and a $\mathrm{C}$ - terminal cytoplasmic domain of 69 residue which is thought to interact with the intracellular actin. MUC1 has many O-linked glycans and proline residues in the tandem-repeat region which gives it a very rigid, extended conformation. MUC1 can be expected to extend up to 0.5 microns from the cell surface based on its size, thus providing an epithelial protective barrier against microorganisms and their cytotoxic agents.

MUC1 was the first mucin cDNA to be sequenced and is expressed in normal epithelia and certain types of malignant cells. An underglycoslylated form of MUC1 has been found to have an over expression in many tumors which had resulted in cell to cell inhibition and interaction with cytotoxic T lymphocytes. Previous studies on MUC1 have shown that the tyrosine and serine residues within the cytoplasmic tails are phosphorylated. A change is this phosphorylation affects cell adhesion. [44, 45].

It has been studied previously that an aberrant glycosylation of MUC1 causes exposure of normally crypted antigens through reduction in the length of the carbohydrate chain. This makes the epitopes of MUC1 very tumor specific. Thus, there could be a relation between the invasion and metastasis of carcinoma cells and mucin MUC1.[46-48] The transmembrane and cytoplasmic subunits of MUC1 pick up the stains during staining of the squamous cells. In a previous study conducted by Nitta et al.[49] using MUC1 and Narashiman et al.[50] with MUC4, positive results were obtained in the Oral Squamous Cell Carcinoma samples. These were highly restricted to the areas that were well-differentiated areas A similar correlation was seen in an immunohistochemical study conducted by Kumar M H.et.al where they found out the number of MUC1 positive cells to be higher in Oral Squamous Cell Carcinoma and Premalignant Diseases as compared to the healthy tissue. There was also an increase in the cellular expression of MUC1 in the lesions with an advance in the grade of dysplasia.[51]

The present study is a novel study where the levels of MUC1 have been studied in the saliva of patients diagnosed with Oral Squamous Cell Carcinoma and Premalignant Diseases. The results of the present study are in accordance to the previous immunohistochemical studies where an upregulation of MUC1 has been observed in tissue expression malignancy. Similarly, in the present study an upregulation of MUC1 levels were observed in the salivary samples of individuals diagnosed with Oral Squamous Cell Carcinoma and premalignant diseases. The limitation of the present study was a small sample size. Similar studies could be conducted over a larger population sample to confirm the results of the present study.

\section{Conclusion}

Within the limitations of the present study it can be concluded that an alteration in the protein MUC1 mucin could play a role in the pathogenesis and progression of epithelial malignancies. Their upregulation in the condition of disease, observed in the salivary samples could make them valuable non-invasive potential biomarkers for detection of oral malignancies.

\section{References}

[1]. Markopoulos AK. Current aspects on oral squamous cell carcinoma. Open Dent. J. 2012;6:126.

[2]. Neville BW, Day TA. Oral cancer and precancerous lesions. CA: Cancer J. Clin.. 2002 Jul;52(4):195-215.

[3]. Warnakulasuriya S, Johnson NW, Van der Waal I. Nomenclature and classification of potentially malignant disorders of the oral mucosa. J Oral Pathol Med. 2007 Nov;36(10):575-80.

[4]. Ganesh R, John J, Saravanan S. Socio demographic profile of oral cancer patients residing in Tamil Nadu - a hospital based study. Indian J Cancer. 
2013 Jan-Mar;50(1):9-13.Pubmed PMID: 23713038.

[5]. Hu S, Arellano M, Boontheung P, Wang J, Zhou H, Jiang J, et al. Salivary proteomics for oral cancer biomarker discovery. Clin. Cancer Res. 2008 Oct $1 ; 14(19): 6246-52$

[6]. Dhivyalakshmi M, Maheswari TU. Expression of salivary biomarkers-Alkaline phosphatase \& lactate dehydrogenase in oral leukoplakia. Int J Chemtech Res. 2014 Aug;6:3014-18.

[7]. Deepa T, Thirrunavukkarasu N. Saliva as a potential diagnostic tool. Indian J. Med. Sci. 2010 Jul 1;64(7):293.

[8]. Tabak LA, Levine MJ, Mandel ID, Ellison SA. Role of salivary mucins in the protection of the oral cavity. J Oral Pathol Med. 1982 Jan;11(1):1-7.

[9]. Tabak LA. In defense of the oral cavity: structure, biosynthesis, and function of salivary mucins. Annu. Rev. Physiol. 1995 Mar;57(1):547-64.

[10]. Slomiany BL, Murty VL, Piotrowski J, Slomiany A. Salivary mucins in oral mucosal defense. Gen Pharmacol: The Vascular System. 1996 Jul $1 ; 27(5): 761-71$.

[11]. Hollingsworth MA, Swanson BJ. Mucins in cancer: protection and control of the cell surface. Nat. Rev. Cancer. 2004 Jan;4(1):45-60.

[12]. Govindaraju L, Gurunathan D. Effectiveness of Chewable Tooth Brush in Children-A Prospective Clinical Study. J Clin Diagn Res. 2017 Mar;11(3):ZC31-ZC34.Pubmed PMID: 28511505.

[13]. Christabel A, Anantanarayanan P, Subash P, Soh CL, Ramanathan M, Muthusekhar MR, et al. Comparison of pterygomaxillary dysjunction with tuberosity separation in isolated Le Fort I osteotomies: a prospective, multi-centre, triple-blind, randomized controlled trial. Int J Oral Maxillofac Surg. 2016 Feb;45(2):180-5.Pubmed PMID: 26338075.

[14]. Soh CL, Narayanan V. Quality of life assessment in patients with dentofacial deformity undergoing orthognathic surgery--a systematic review. Int J Oral Maxillofac Surg. 2013 Aug;42(8):974-80.Pubmed PMID: 23702370.

[15]. Mehta M, Deeksha, Tewari D, Gupta G, Awasthi R, Singh H, et al. Oligonucleotide therapy: An emerging focus area for drug delivery in chronic inflammatory respiratory diseases. Chem Biol Interact. 2019 Aug 1;308:206215.Pubmed PMID: 31136735

[16]. Ezhilarasan D, Apoorva VS, Ashok Vardhan N. Syzygium cumini extract induced reactive oxygen species-mediated apoptosis in human oral squamous carcinoma cells. J Oral Pathol Med. 2019 Feb;48(2):115-121.Pubmed PMID: 30451321.

[17]. Campeau PM, Kasperaviciute D, Lu JT, Burrage LC, Kim C, Hori M, et al. The genetic basis of DOORS syndrome: an exome-sequencing study. Lancet Neurol. 2014 Jan;13(1):44-58.Pubmed PMID: 24291220.

[18]. Sneha S. Knowledge and awareness regarding antibiotic prophylaxis for infective endocarditis among undergraduate dental students. Asian J Pharm Clin Res. 2016 Oct 1:154-9.

[19]. Christabel SL, Linda Christabel S. Prevalence of type of frenal attachment and morphology of frenum in children, Chennai, Tamil Nadu. World J Dent. 2015 Oct;6(4):203-7

[20]. Kumar S, Rahman R. Knowledge, awareness, and practices regarding biomedical waste management among undergraduate dental students. Asian J Pharm Clin Res. 2017;10(8):341.

[21]. Sridharan G, Ramani P, Patankar S. Serum metabolomics in oral leukoplakia and oral squamous cell carcinoma. J Cancer Res Ther. 2017 Jul 1;13(3):55661.

[22]. Ramesh A, Varghese SS, Doraiswamy JN, Malaiappan S. Herbs as an antioxidant arsenal for periodontal diseases. J Intercult Ethnopharmacol. 2016 Jan 27;5(1):92-6.Pubmed PMID: 27069730

[23]. Thamaraiselvan M, Elavarasu S, Thangakumaran S, Gadagi JS, Arthie T. Comparative clinical evaluation of coronally advanced flap with or without platelet rich fibrin membrane in the treatment of isolated gingival recession. J Indian Soc Periodontol. 2015 Jan;19(1):66-71.

[24]. Thangaraj SV, Shyamsundar V, Krishnamurthy A, Ramani P, Ganesan K, Muthuswami M, et al. Molecular Portrait of Oral Tongue Squamous Cell Carcinoma Shown by Integrative Meta-Analysis of Expression Profiles with Validations. PLoS One. 2016 Jun 9;11(6):e0156582.Pubmed PMID: 27280700 .

[25]. Ponnulakshmi R, Shyamaladevi B, Vijayalakshmi P, Selvaraj J. In silico and in vivo analysis to identify the antidiabetic activity of beta sitosterol in adipose tissue of high fat diet and sucrose induced type- 2 diabetic experimental rats. Toxicol Mech Methods. 2019 May;29(4):276-290.Pubmed PMID: 30461321

[26]. Ramakrishnan M, Shukri M. Fluoride, Fluoridated Toothpaste Efficacy And Its Safety In Children-Review. Int J Pharm Res. 2018 Oct 1;10(04):109-14.

[27]. Vijayashree Priyadharsini J. In silico validation of the non-antibiotic drugs acetaminophen and ibuprofen as antibacterial agents against red complex pathogens. J Periodontol. 2019 Dec;90(12):1441-1448.Pubmed PMID: 31257588 .

[28]. Pc J, Marimuthu T, Devadoss P, Kumar SM. Prevalence and measurement of anterior loop of the mandibular canal using CBCT: A cross sectional study.
Clin Implant Dent Relat Res. 2018 Apr 6;20(4):531-4.

[29]. Ramesh A, Varghese S, Jayakumar ND, Malaiappan S. Comparative estimation of sulfiredoxin levels between chronic periodontitis and healthy patients - A case-control study. J Periodontol. 2018 Oct;89(10):1241-1248.Pubmed PMID: 30044495.

[30]. Ramadurai N, Gurunathan D, Samuel AV, Subramanian E, Rodrigues SJ. Effectiveness of $2 \%$ Articaine as an anesthetic agent in children: randomized controlled trial. Clin Oral Investig. 2019 Sep;23(9):3543-50.

[31]. Sridharan G, Ramani P, Patankar S, Vijayaraghavan R. Evaluation of salivary metabolomics in oral leukoplakia and oral squamous cell carcinoma. J Oral Pathol Med. 2019 Apr;48(4):299-306.

[32]. Mathew MG, Samuel SR, Soni AJ, Roopa KB. Evaluation of adhesion of Streptococcus mutans, plaque accumulation on zirconia and stainless steel crowns, and surrounding gingival inflammation in primary molars: randomized controlled trial. Clin Oral Investig. 2020 Sep;24(9):3275-3280.Pubmed PMID: 31955271.

[33]. Samuel SR. Can 5-year-olds sensibly self-report the impact of developmental enamel defects on their quality of life? Int J Paediatr Dent. 2021 Mar;31(2):285-286.Pubmed PMID: 32416620.

[34]. R H, Ramani P, Ramanathan A, R JM, S G, Ramasubramanian A, et al. CYP2 C9 polymorphism among patients with oral squamous cell carcinoma and its role in altering the metabolism of benzo[a]pyrene. Oral Surg Oral Med Oral Pathol Oral Radiol. 2020 Sep;130(3):306-312.Pubmed PMID: 32773350 .

[35]. Chandrasekar R, Chandrasekhar S, Sundari KKS, Ravi P. Development and validation of a formula for objective assessment of cervical vertebral bone age. Prog Orthod. 2020 Oct 12;21(1):1-8.Pubmed PMID: 33043408.

[36]. Vijayashree Priyadharsini J, Smiline Girija AS, Paramasivam A. In silico analysis of virulence genes in an emerging dental pathogen A. baumannii and related species. Arch Oral Biol. 2018 Oct;94:93-98.Pubmed PMID: 30015217.

[37]. Radhakrishnan R, Shrestha B, Bajracharya D. Oral Cancer-An Overview. 2018.

[38]. George A, Sreenivasan BS, Sunil S, Varghese SS, Thomas J, Gopakumar D, et al. Potentially malignant disorders of oral cavity. Oral Maxillofac Pathol J. 2011 Jan 1;2(1):94-100

[39]. Marocchio LS, Lima J, Sperandio FF, Corrêa L, de Sousa SO. Oral squamous cell carcinoma: an analysis of 1,564 cases showing advances in early detection. J Oral Sci. 2010 Jun;52(2):267-73.Pubmed PMID: 20587952.

[40]. Rabassa ME, Croce MV, Pereyra A, Segal-Eiras A. MUC1 expression and anti-MUC1 serum immune response in head and neck squamous cell carcinoma (HNSCC): a multivariate analysis. BMC Cancer. 2006 Oct 25;6:253. Pubmed PMID: 17064405.

[41]. Frenkel ES, Ribbeck K. Salivary mucins in host defense and disease prevention. J. Oral Microbiol. 2015 Jan 1;7(1):29759.

[42]. Offner GD, Troxler RF. Heterogeneity of high-molecular-weight human salivary mucins. Adv. Dent. Res. 2000 Dec;14(1):69-75.

[43]. Nath D, Hartnell A, Happerfield L, Miles DW, Burchell J, Taylor-Papadimitriou J, et al. Macrophage-tumour cell interactions: identification of MUC1 on breast cancer cells as a potential counter-receptor for the macrophagerestricted receptor, sialoadhesin. Immunology. 1999 Oct;98(2):213-9.Pubmed PMID: 10610356.

[44]. Hanisch FG, Müller S. MUC1: the polymorphic appearance of a human mucin. Glycobiology. 2000 May 1;10(5):439-49.

[45]. Gendler SJ, Lancaster CA, Taylor-Papadimitriou J, Duhig T, Peat N, Burchell $\mathrm{J}$, et al. Molecular cloning and expression of human tumor-associated polymorphic epithelial mucin. J. Biol. Chem. 1990 Sep 5;265(25):15286-93.

[46]. Rachagani S, Torres MP, Moniaux N, Batra SK. Current status of mucins in the diagnosis and therapy of cancer. Biofactors. 2009 Nov;35(6):509-27.

[47]. Pereira MC, Oliveira DT, Landman G, Kowalski LP. Histologic subtypes of oral squamous cell carcinoma: prognostic relevance. J Can Dent Assoc. 2007 May 1;73(4):339-344.

[48]. Mahomed F. Recent advances in mucin immunohistochemistry in salivary gland tumors and head and neck squamous cell carcinoma. Oral Oncol. 2011 Sep;47(9):797-803.Pubmed PMID: 21723776.

[49]. Nitta T, Sugihara K, Tsuyama S, Murata F. Immunohistochemical study of MUC1 mucin in premalignant oral lesions and oral squamous cell carcinoma: association with disease progression, mode of invasion, and lymph node metastasis. Cancer. 2000 Jan 15;88(2):245-54.Pubmed PMID: 10640953

[50]. Narashiman S, Narasimhan M, Venkatraman G. Expression of Mucin 4 in leukoplakia and oral squamous cell carcinoma: An immunohistochemical study. J Oral Maxillofac Pathol. 2014 Jan;18(1):25-31.Pubmed PMID: 24959033.

[51]. Kumar MH, Sanjai K, Kumarswamy J, Keshavaiah R, Papaiah L, Divya S Expression of MUC1 mucin in potentially malignant disorders, oral squamous cell carcinoma and normal oral mucosa: An immunohistochemical study. J. Oral Maxillofac. Pathol.. 2016 May;20(2):214. 